\title{
Sea cucumbers collected by the Kermadec Biodiscovery Expedition 2011 (Echinodermata: Holothuroidea: Apodida and Dendrochirotida)
}

\author{
P MARK O'LOUGHLIN ${ }^{1} \&$ DIDIER VANDENSPIEGEL ${ }^{2}$ \\ 1. Marine Biology Section, Museum Victoria, GPO Box 666, Melbourne, Victoria 3001, Australia (pmoloughlin@edmundrice.org) \\ ${ }^{2}$ Musée royal de l'Afrique centrale, Section invertebrés non-insects, B-3080, Tervuren, Belgium (dvdspiegel@africamuseum.be)
}

\begin{abstract}
Three shallow holothuroid species are recorded for the rocky shoreline of the Kermadec Islands. The new apodid species Chiridota kermadeca sp. nov. is described. Two dendrochirotid species are reported, both previously found in New Zealand: Plesiocolochirus ignavus (Ludwig, 1875) and Pseudocnus sentus O'Loughlin \& Alcock, 2000.
\end{abstract}

\section{Résumé}

Trois espèces peu profondes d'holothuries ont été observées sur le rivage rocheux des îles de Kermadec. Deux d'entre elles appartiennent à deux espèces de dendrochirotid également connues de Nouvelle Zélande: Plesiocolochirus ignavus (Ludwig, 1875) et Pseudocnus sentus O'Loughlin \& Alcock, 2000. La troisième espèce: Chiridota kermadeca sp. nov., nouvelle pour la science, est décrite.

Key words: Sea cucumber, Apodida, Dendrochirotida, Chiridota, Plesiocolochirus, Pseudocnus, new species, Kermadec

\section{Introduction}

To date there is no comprehensive inventory of the invertebrate fauna of intertidal and subtidal habitats of the Kermadec Islands. With a view to addressing this challenge the Kermadec Biodiscovery Expedition on RV Braveheart visited the islands from 9 to 29 of May 2011, under the leadership of Dr. Tom Trnski of the Auckland Museum and in collaboration with the Museum of New Zealand Te Papa Tongarewa, Australian Museum and New Zealand Department of Conservation. Benham (1912) has provided the only report of shallow holothuroid echinoderms for the Kermadec Islands: the aspidochirotid Holothuria (Platyperona) difficilis (Selenka, 1867) (as Actinopyga (Muelleria) parvula) and the apodid Chiridota rigida Semper, 1867 (as Chirodota rigida). Hansen (1975) has reported on the abyssal holothuroids from the Kermadec Trench. This paper describes a new apodid species, possibly that reported previously by Benham (1912) as Chiridota rigida Semper, and two dendrochirotid species reported for the Kermadec Islands for the first time. Two Australian Museum expeditioners, Stephen Keable and Amanda Reid, are preparing a paper for the Bulletin of the Auckland Museum on the marine invertebrates collected during the Expedition.

\section{Methods}

Scanning electron microscope (SEM) images were taken by Didier VandenSpiegel after clearing the ossicles of associated soft tissue in commercial bleach, air-drying, mounting on aluminium stubs, and coating with gold. Observations were made using a JEOL JSM-6480LV SEM. Measurements were made with Smile view software. Photos of the preserved new holotype were taken by Shari Barmos with a Nikon 300s DSLR camera, using a 
Nikkor $105 \mathrm{~mm}$ lens and 2x adaptor / teleconverter. The calcareous ring plates photo was taken by Melanie Mackenzie using a Leica 205C microsystem with Leica Application suite version 3.8 automontage software.

Abbreviations

AIM Auckland War Memorial Museum (catalogue number prefix MA).

AM Australian Museum (registration number prefix J).

NMV Museum Victoria.

NIWA New Zealand National Institute of Water and Atmospheric Research.

Numbers in brackets after registrations refer to numbers of specimens in lots.

\section{Apodida Brandt, 1835}

\section{Chiridotidae Østergren, 1898}

\section{Chiridota kermadeca sp. nov.}

Figures $1 \& 2$.

? Chiridota rigida Semper, 1868.—Benham, 1912: 136 (non Chiridota rigida Semper, 1867).

Material examined. Holotype. Kermadec Islands, Stawell Shoal, north of Stella Passage, $30.5297^{\circ} \mathrm{S}, 178.5594^{\circ}$ W, 21-24 m, SCUBA, collected S. Keable and A. Reid, 25 May 2011, fixed and preserved 95\% ethanol, AIM MA73394 (female).
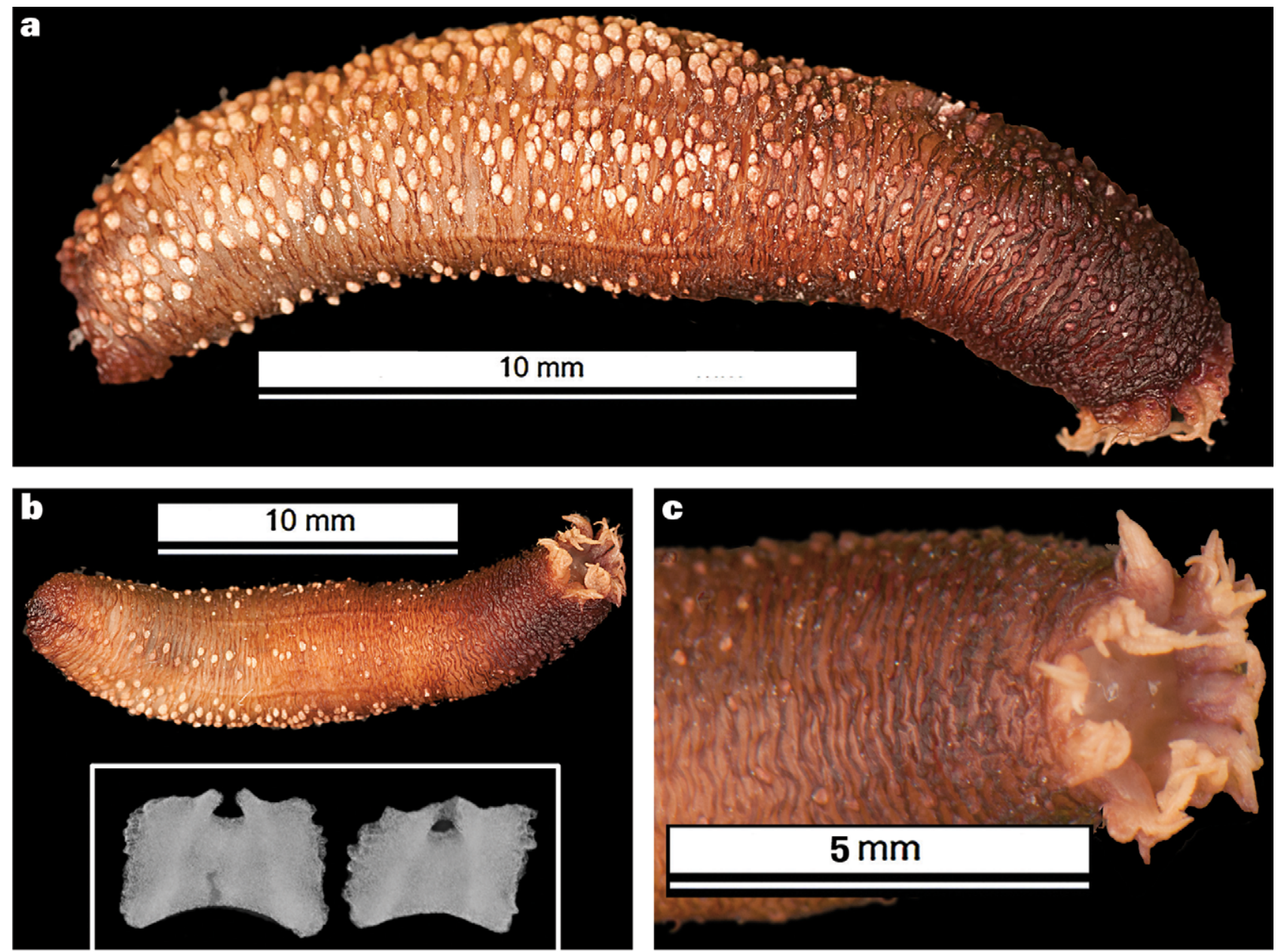

FIGURE 1. Photos of holotype of Chiridota kermadeca sp. nov. (AIM MA73394). a, right dorso-lateral view; b, left ventral inter-radial view, insert with photo of 2 radial plates of the calcareous ring of a paratype (AIM MA73395); c, tentacle crown. 


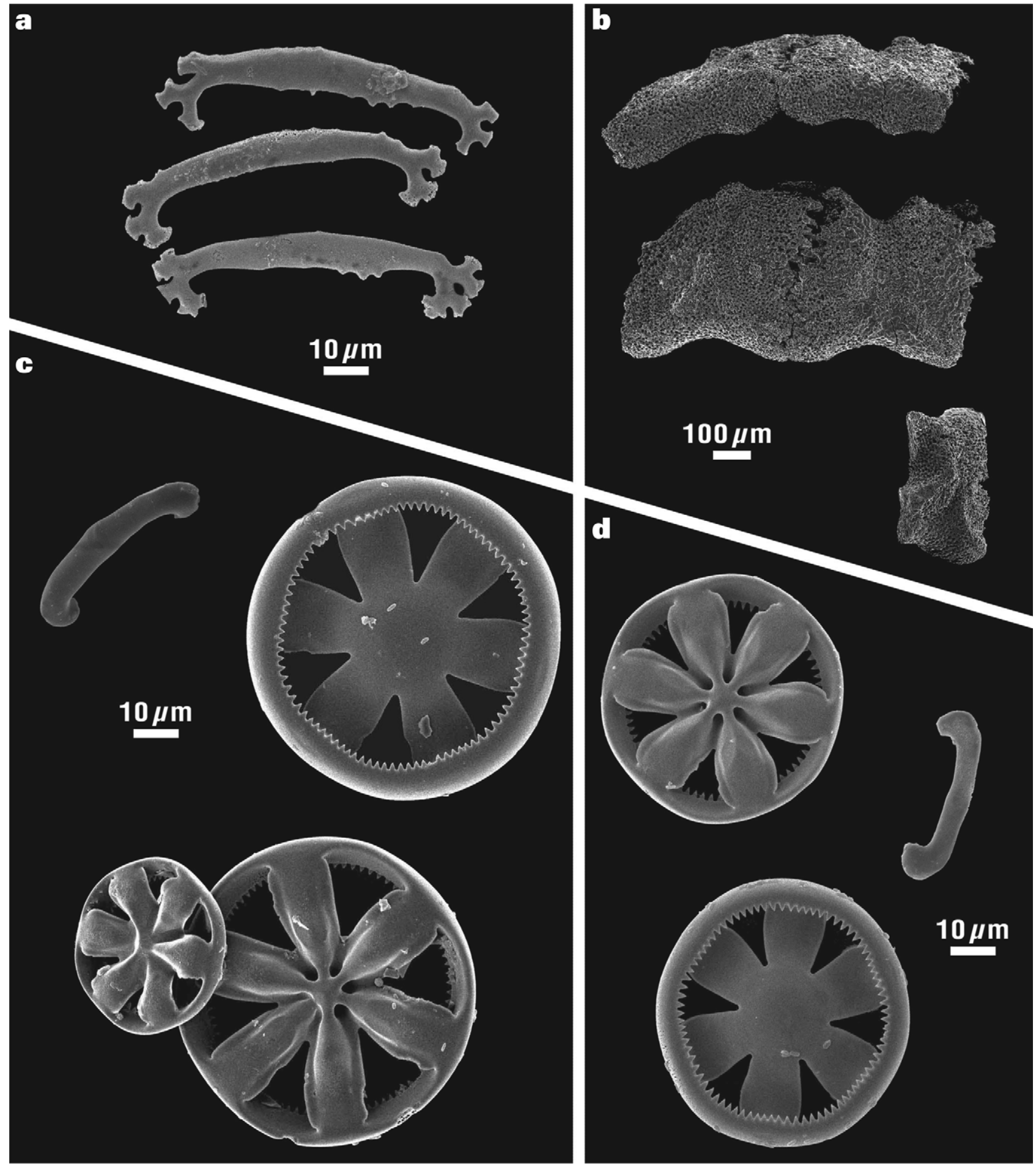

FIGURE 2. SEM images of ossicles and ring plates from paratype of Chiridota kermadeca sp. nov. (AIM MA73395). a, rod ossicles from tentacle; b, top and middle showing radial plate (left) and inter-radial plate (right) from the calcareous ring, bottom showing inter-radial plate; c, wheels and rod ossicles from dorsal papilla; $d$, wheels and rod ossicles from ventral papilla.

Paratype. Same site and preservation history, 20 May 2011, AIM MA73395 (specimen and slide with cleared calcareous ring plates; male).

Other material. Boat Cove, 10 m, 15 May 2011, fixed 10\% formalin, preserved 70\% ethanol, AM J24973 (1); AM J25393 (2).

Diagnosis. Apodid species up to $20 \mathrm{~mm}$ long, up to $5 \mathrm{~mm}$ diameter (preserved, strongly contracted, tentacles not withdrawn); ossicles in transverse oval papillae clusters in the body wall, clusters up to $0.3 \mathrm{~mm}$ long, numerous 
and close over all of dorsal and dorso-lateral inter-radii, few and scattered on both ventral inter-radii; tentacles 10 , smaller ventrally, digits 5-6 pairs per tentacle, longest distally; radial calcareous ring plates more broad than high, 2 plates with anterior notches, one notch incipiently closed, plates not perforated, inter-radial plates irregular in form, higher than broad; 4 polian vesicles; gonad tubules in holotype longer than contracted body, filled with eggs; ciliated funnels minute, in single series along both ventral inter-radii and right ventro-lateral inter-radius; body wall ossicles wheels, rods; wheels with 6 spokes, continuous teeth on inner margin, wheels larger dorsally than ventrally, diameters $40-80 \mu \mathrm{m}$; rods few, distinctly C-shaped, ends slightly swollen, rugose, not spinous or branched, 36-56 $\mu \mathrm{m}$ long; tentacle rods typically $70 \mu \mathrm{m}$ long, some blunt spines along rods, 3-4 branches distally, truncate ends with few blunt spines.

Colour (preserved). Alcohol-fixed specimen body dark purplish-brown, with purplish-brown to off-while transverse oval spots (biggest $0.3 \mathrm{~mm}$ long), abundant and close dorsally and dorso-laterally, scattered and sparse ventrally; gonad tubules white; formalin-fixed specimen pink, with off-white spots; tentacles off-white.

Distribution. Kermadec Islands, Stawell Shoal and Boat Cove, 10-24 m.

Etymology. Named for the Kermadec Islands as the type locality and only known distribution for this species.

Remarks. The tentacle number in Chiridota kermadeca sp. nov. is 10, not the typical 12 tentacles for species of Chiridota Eschscholtz, 1829. This and the remaining combination of morphological characters distinguish the new species from other Chiridota species discussed with keys by Clark (1908) and Heding (1928). It is not Chiridota rigida Semper, 1867, thought to be widespread in the Indo-Pacific oceans (A. M. Clark \& Rowe 1971), and reported previously by Benham (1912) with some reservation for the Kermadec Islands, by Rowe \& Doty (1977) for Guam, by Thandar \& Rowe (1989) for southern Africa, and by Rowe \& Gates (1995) for Australia. Chiridota rigida has many fewer dorsal ossicle papillae, 12 tentacles, calcareous ring plates with pores, and body wall rods weakly branched, and not distinctly C-shaped. Chiridota kermadeca sp. nov. is not one of the four Chiridota species reported by Pawson (1970) for New Zealand: Chiridota carnelyensis Mortensen, 1925 (white, lacking body wall rods); Chiridota gigas Dendy \& Hindle, 1907 (12 tentacles, body wall rods spinous distally, ossicle papillae merge mid-body); Chiridota nigra Mortensen, 1925 (lacking body wall rods, lacking ventral ossicle papillae, black); Chiridota mortenseni Pawson, 1962 (body wall rods spinous, tentacle rods smooth and not extensively bifurcating, radial plates of calcareous ring perforated). It is not Chiridota hawaiiensis Fisher, 1907 (12 tentacles each with 4-5 pairs of digits, ossicle papillae tending to be in 5 irregular longitudinal inter-radial series, body wall rods not distinctly C-shaped). We note that the date of publication of species Chiridota rigida by Semper was 1867.

\section{Dendrochirotida Grube, 1840}

\section{Cucumariidae Ludwig, 1894}

\section{Plesiocolochirus ignavus (Ludwig, 1875)}

Figure 3.

Material examined. Kermadec Islands, Meyer Island, rock wall scrapings, 6-15 m, collected S. Keable and A. Reid, 19 May 2011, fixed 10\% formalin, preserved 70\% ethanol, AIM MA30358 (1); AM J24974 (2).

Remarks. As recorded by Rowe and Gates (1995), Plesiocolochirus ignavus (Ludwig, 1875) is found across southern Australia, and in our experience is one of the most abundant holothuroids. O'Loughlin \& Alcock (2000) reported its occurrence in New Zealand in Hauraki Gulf $(20 \mathrm{~m})$ on the NE of the North Island, and in Dusky Sound (11-18 m). The Kermadec specimens are not the tropical species Plesiocolochirus australis (Ludwig, 1875) of northern Australia. Its occurrence on the Kermadec Islands is an extension of its distribution.

\section{Pseudocnus sentus O'Loughlin \& Alcock, 2000}

Figure 4.

Material examined. Meyer Island, rock wall scrapings, 6-15 m, collected S. Keable and A. Reid, 19 May 2011, fixed 10\% formalin, preserved 70\% ethanol, AIM MA30360 (3); AM J24983 (4). 


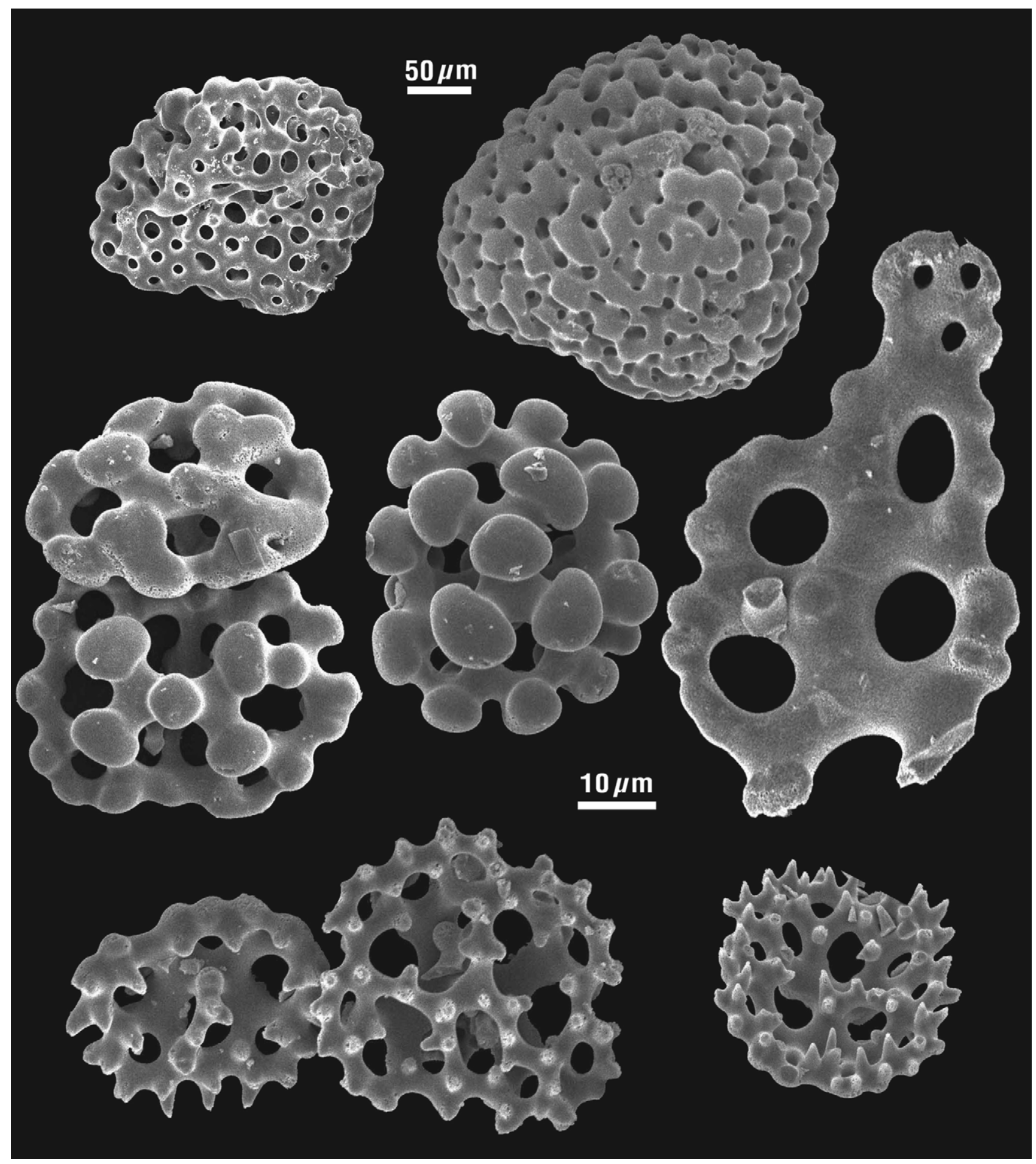

FIGURE 3. SEM images of ossicles from body wall of Plesiocolochirus ignavus (Ludwig, 1875) (AIM MA30358). Top, multi-layered ossicles; middle left and centre, knobbed buttons; middle right, part of tube foot support rod; bottom, bridged (middle) and partly bridged spinous cups.

Remarks. Pseudocnus sentus O'Loughlin \& Alcock, 2000 was initially reported for Paterson Inlet on Stewart Island at 0-4 m. Nicola Davey (pers. comm.) has subsequently found the species in the New Zealand Bay of Islands at less than $10 \mathrm{~m}$. Its occurrence on the Kermadec Islands is a distribution extension. 


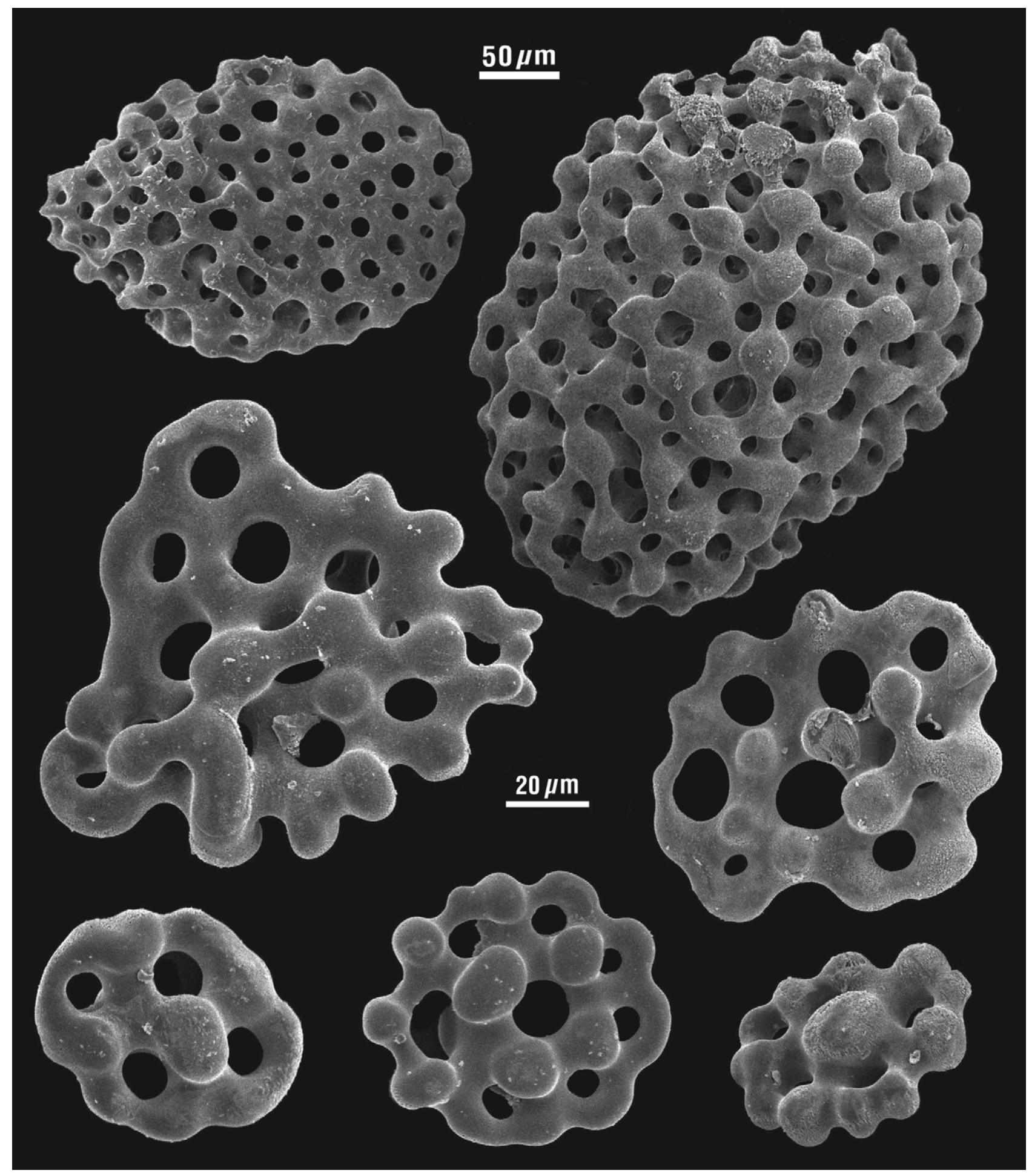

FIGURE 4. SEM images of ossicles from body wall of Pseudocnus sentus O'Loughlin \& Alcock, 2000 (AIM MA30360). Top, multi-layered ossicles; middle left, knobbed plate with secondary developments and terminal blunt marginal teeth (right); middle right and bottom, knobbed plates and buttons.

\section{Acknowledgments}

We are appreciative of the thorough work of the participants in the Kermadec Biodiscovery Expedition 2011, and in particular of the collecting by Stephen Keable and Amanda Reid (AM) who provided the few small holothuroid specimens that we have examined. We are grateful for the assistance of Stephen Keable and Helen Stoddart (AM), 
and Tom Trnski and Dhahara Ranatunga (AIM), who helped facilitate our systematic work on this material; for the photography of the holotype specimen by Shari Barmos (NMV); for the photograph of calcareous ring plates by Melanie Mackenzie (NMV); for the relevant distribution information provided by Nicola Davey (NIWA); and for the format of the figures by Ben Boonen. We are grateful for the critical comments on our manuscript by our valued colleague Frank Rowe and an anonymous reviewer.

\section{References}

Benham, W.B. (1912) Report on sundry invertebrates from the Kermadec Islands. Transactions of the New Zealand Institute (for 1911), 44(12), 135-138.

Clark, A.M. \& Rowe, F.W.E. (1971) Monograph of shallow-water Indo-West Pacific echinoderms. Pp. vii+238, 100 figs, 31 pls. British Museum (Natural History), London.

Clark, H.L. (1908) The apodous holothurians. Smithsonian Contributions to Knowledge, 35, 1-231, pls 1-13.

Dendy, A. \& Hindle, E. (1907) Some additions to our knowledge of the New Zealand holothurians. Journal of the Linnean Society (Zoology), 30, 95-125, pls 11-14.

Fisher, W.K. (1907) The holothurians of the Hawaiian Islands. Proceedings of the United States National Museum, 32(1555), 637-744, pls 66-82.

Hansen, B. (1975) Systematics and biology of the deep-sea holothurians. Part I. Elasipoda. Galathea Report, 13, 1-262, pls $1-14$.

Heding, S. (1928) Synaptidae. Papers from Dr. Th. Mortensen's Pacific Expedition 1914-1916. No. 66. Videnskabelige Meddelelser fra Dansk naturhistorisk Forening i Kфbenhavn, 85, 105-323, 2 pls.

Keable, S. \& Reid, A. (in preparation) Marine invertebrates collected during the Kermadec Biodiscovery Expedition 2011. Bulletin of the Auckland Museum.

Ludwig, H. (1875) Beiträge zur Kenntnis der Holothurien. Arbeiten aus dem Zoologisch-Zootomischen Institut in Würzburg, 2 , 77-118, pls 6, 7.

Mortensen, Th. (1925) Echinoderms of New Zealand and the Auckland-Campbell Islands. III-V. Asteroidea, Holothurioidea, Crinoidea. Videnskabelige Meddelelser fra Dansk naturhistorisk Forening i Kobenhavn, 79(29), 261-420, text figs 1-70, pls 12-14.

O’Loughlin, P.M. \& Alcock, N. (2000) The New Zealand Cucumariidae (Echinodermata, Holothuroidea). Memoirs of Museum Victoria, 58(1), 1-24.

Pawson, D.L. (1962) Chiridota mortenseni n. sp., a new apodous holothurian from New Zealand. Transactions of the Royal Society of New Zealand, Zoology, 2(10), 61-64, figs 1-5.

Pawson, D.L. (1970) The marine fauna of New Zealand: Sea cucumbers (Echinodermata: Holothuroidea). Bulletin of the New Zealand Department of Scientific and Industrial Research, 201, 7-65, 10 figs, 2 pls.

Rowe, F.W.E. \& Doty, J.E. (1977) The shallow-water holothurians of Guam. Micronesica, 13(2), 217-250.

Rowe, F.W.E. \& Gates, J. (1995) Echinodermata. In: Wells, A. (ed.), Zoological Catalogue of Australia 33, i-xiii, 1-510. CSIRO, Melbourne.

Semper, C. (1867) Holothurien. Reisen im Archipel der Philippinen 1, 1-288, pls 1-40.

Thandar, A.S. \& Rowe, F.W.E. (1989) New species and new records of apodous holothurians (Echinodermata, Holothuroidea) from southern Africa. Zoologica Scripta, 18(1), 145-155. 